\title{
Clinical perspective for the practicing neurologist
}

\author{
A new journal?
}

John R. Corboy, MD,

FAAN

Robert A. Gross, MD, PhD, FAAN

Address correspondence and reprint requests to Dr. John R. Corboy, University of Colorado, Denver, 12631 East 17th Avenue, B185, Aurora, CO 80045 john.corboy@ucdenver.edu

Neurology ${ }^{\circledR}$ Clinical Practice 2010;75(Suppl 1):S1
T he issue of Neurology: Clinical Practice that you are reading is a new feature of the journal. In response to feedback from American Academy of Neurology (AAN) members, we undertook to provide new content, with a new perspective, that complements the rich scientific and related fare in the parent journal.

Neurology has entered an exciting phase of scientific discovery and rapid advancement in therapeutic options, resulting in a more complicated landscape for the practicing neurologist. As practitioners we also face increasingly rigorous maintenance of certification requirements. A variety of publications, including Neurology ${ }^{\circledR}$, have done an excellent job of relaying new scientific discoveries pertinent to neurologists. In discussions with friends and colleagues over the years, however, it has become apparent that the dissemination and application of these discoveries into the practice of neurology has been challenging, as many publications are geared to primary research articles, with limited practical relevance for the practicing neurologist. These expressed views complement and support the views expressed by AAN members in surveys.

Today we launch an exciting new publication, Neurology: Clinical Practice (NCP), geared specifically toward filling that void. In this inaugural issue, we offer a number of different types of articles, including the following:

- "Five new things in..." The goal of these articles, on topics including Parkinson disease, multiple sclerosis, gliomas, and stroke, is to update practicing neurologists on emerging issues in various important fields.

- "Approach to the patient with..." The focus in these articles will be a practical discussion of problems faced by the practicing neurologist caring for a complex patient.

- "Cases." Utilizing 2 different formats, both short (an interesting image and brief discussion) and long (a full case, with longer discussion), we hope to offer interesting and timely cases with important teaching points.

- "Ethical issues." Neurologists are faced every day with challenging ethical issues, often with no clear answer. These discussions will help identify the issues to help in dealing with ethical concerns.

- "The challenging patient." This might be a difficult personal interaction or a complex clinical problem.

- "Practice issues." These articles will highlight issues related to office function, such as incorporation of electronic medical records.

- "Health policy." Discussions of health policy issues, with special emphasis on changes in national health care policy as it affects neurologists.

We hope you find these articles stimulating, educational, and useful to you in your practice. One more issue of NCP is planned; as with this issue, it will appear as a supplement to Neurology ${ }^{\circledR}$. If successful, we will launch $N C P$ as a full-time journal in the family of publications under the auspices of the AAN. One measure of success will be your response to our initial efforts: after these issues appear, we will ask for your feedback via a survey in which we will seek your honest opinions and your constructive suggestions on how we might best tailor a publication like NCP to your needs and goals. We look forward to hearing from you.

\section{DISCLOSURE}

Dr. Corboy serves as Editor for Neurology: Clinical Practice and as Section Editor for Neurology Today; serves as a consultant for Bayer Schering Pharma, EMD Serono, Inc., Advanced Studies in Medicine (ASiM), and Novartis; has received research support from Novartis, BioMS Medical, Orasi Medical Inc., the NIH/NINDS (1UO1NS4571901A1 [PI]), and the National MS Society; and has reviewed files and give expert testimony in medico-legal cases. $\mathrm{He}$ is a part-time employee of the Denver Veterans Medical Center. Dr. Gross receives an honorarium from AAN as Editor-in-Chief of Neurology ${ }^{\circledR}$; has received research funding from the Department of the Army and UCBPharma; is supported for educational endeavors by the University of Rochester Medical Center's Clinical and Translational Science Award from the NIH; has conducted clinical trials over the past 5 years funded by GlaxoSmithKline, UCB, Ortho-McNeil, Pfizer, and Marinus; and has served on the speakers' bureaus for Abbott, UCB, and GlaxoSmithKline and has received consultant fees from GlaxoSmithKline and Harris Interactive. Since his appointment as Editor-in-Chief, Dr. Gross has ceased participation in industry-sponsored clinical trials and speakers' bureaus.

From the Department of Neurology (J.R.C.), University of Colorado, Denver, and Denver Veterans Affairs Medical Center, Denver, CO; and the Strong Epilepsy Center (R.A.G.), University of Rochester Medical Center, Rochester, NY. 


\section{Neurology}

\section{Clinical perspective for the practicing neurologist: A new journal? John R. Corboy and Robert A. Gross \\ Neurology 2010;75; S1 \\ DOI 10.1212/WNL.0b013e3181fe41d7}

\section{This information is current as of November 1,2010}

\section{Updated Information \&}

Services

Permissions \& Licensing

Reprints including high resolution figures, can be found at:

http://n.neurology.org/content/75/18_Supplement_1/S1.full

Information about reproducing this article in parts (figures,tables) or in its entirety can be found online at:

http://www.neurology.org/about/about_the_journal\#permissions

Information about ordering reprints can be found online:

http://n.neurology.org/subscribers/advertise

Neurology ${ }^{\circledR}$ is the official journal of the American Academy of Neurology. Published continuously since 1951, it is now a weekly with 48 issues per year. Copyright Copyright (? 2010 by AAN Enterprises, Inc.. All rights reserved. Print ISSN: 0028-3878. Online ISSN: 1526-632X.

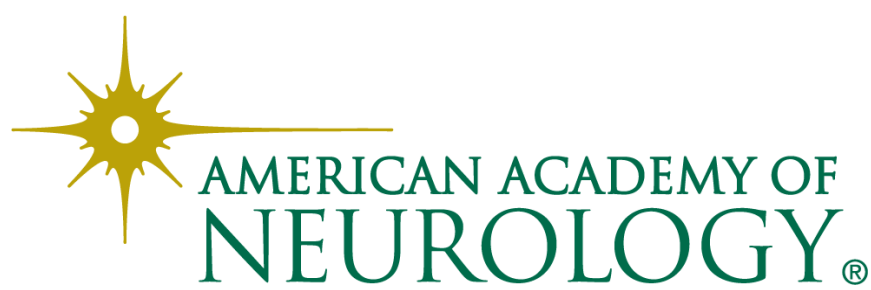

